\title{
Stage III Non-Small Cell Lung Cancer in the elderly: Patient characteristics predictive for tolerance and survival of chemoradiation in daily clinical practice
}

Citation for published version (APA):

Driessen, E. J. M., Bootsma, G. P., Hendriks, L. E. L., van den Berkmortel, F. W. P. J., Bogaarts, B. A. H. A., van Loon, J. G. M., Dingemans, A-M. C., \& Janssen - Heijnen, M. (2016). Stage III Non-Small Cell Lung Cancer in the elderly: Patient characteristics predictive for tolerance and survival of chemoradiation in daily clinical practice. Radiotherapy and Oncology, 121(1), 26-31.

https://doi.org/10.1016/j.radonc.2016.07.025

Document status and date:

Published: 01/10/2016

DOI:

10.1016/j.radonc.2016.07.025

Document Version:

Publisher's PDF, also known as Version of record

Document license:

Taverne

Please check the document version of this publication:

- A submitted manuscript is the version of the article upon submission and before peer-review. There can be important differences between the submitted version and the official published version of record.

People interested in the research are advised to contact the author for the final version of the publication, or visit the DOI to the publisher's website.

- The final author version and the galley proof are versions of the publication after peer review.

- The final published version features the final layout of the paper including the volume, issue and page numbers.

Link to publication

\footnotetext{
General rights rights.

- You may freely distribute the URL identifying the publication in the public portal. please follow below link for the End User Agreement:

www.umlib.nl/taverne-license

Take down policy

If you believe that this document breaches copyright please contact us at:

repository@maastrichtuniversity.nl

providing details and we will investigate your claim.
}

Copyright and moral rights for the publications made accessible in the public portal are retained by the authors and/or other copyright owners and it is a condition of accessing publications that users recognise and abide by the legal requirements associated with these

- Users may download and print one copy of any publication from the public portal for the purpose of private study or research.

- You may not further distribute the material or use it for any profit-making activity or commercial gain

If the publication is distributed under the terms of Article $25 \mathrm{fa}$ of the Dutch Copyright Act, indicated by the "Taverne" license above, 
Lung cancer in the elderly

\title{
Stage III Non-Small Cell Lung Cancer in the elderly: Patient characteristics predictive for tolerance and survival of chemoradiation in daily clinical practice
}

\author{
Elisabeth J.M. Driessen ${ }^{\text {a,* }}$, Gerbern P. Bootsma ${ }^{\mathrm{b}}$, Lizza E.L. Hendriks ${ }^{c}$, Franchette W.P.J. van den \\ Berkmortel $^{\mathrm{d}}$, Brigitte A.H.A. Bogaarts ${ }^{\mathrm{e}}$, Judith G.M. van Loon ${ }^{\mathrm{f}}$, Anne-Marie C. Dingemans ${ }^{\mathrm{c}}$, \\ Maryska L.G. Janssen-Heijnen ${ }^{\text {a,g }}$
}

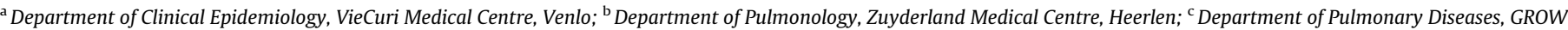

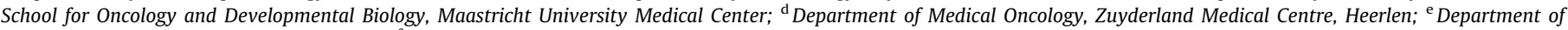

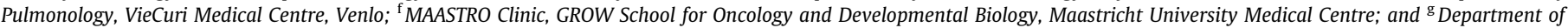
Epidemiology, Maastricht University Medical Centre, GROW School for Oncology and Developmental Biology, The Netherlands

\section{A R T I C L E I N F O}

\section{Article history:}

Received 22 February 2016

Received in revised form 25 July 2016

Accepted 31 July 2016

Available online 10 August 2016

\section{Keywords:}

Non-Small Cell Lung Cancer

Elderly

Chemoradiation

Tolerance

Survival

Motives

\begin{abstract}
A B S T R A C T
Background: In unselected elderly with stage III Non-Small Cell Lung Cancer (NSCLC), evidence is scarce regarding motives and effects of treatment modalities.

Methods: Hospital-based multicenter retrospective study including unresectable stage III NSCLC patients aged $\geqslant 70$ and diagnosed between 2009 and $2013(N=216)$. Treatment motives and tolerance (no unplanned hospitalizations and completion of treatment), and survival were derived from medical records and the Netherlands Cancer Registry.

Results: Patients received concurrent chemoradiation (cCHRT, 33\%), sequential chemoradiation (sCHRT, $24 \%$ ), radical radiotherapy (RT, $16 \%$ ) or no curative treatment (27\%). Comorbidity, performance status (58\%) and patient refusal (15\%) were the most common motives for omitting cCHRT. Treatment tolerance for cCHRT and sCHRT was worse in case of severe comorbidity (OR 6.2 (95\%CI 1.6-24) and OR $6.4(95 \% \mathrm{CI}$ $1.8-22$ ), respectively). One-year survival was $57 \%, 50 \%, 49 \%$ and $26 \%$ for CCHRT, sCHRT, RT and no curative treatment, respectively. Compared to CCHRT, survival was worse for no curative treatment $(P=0.000)$, but not significantly worse for SCHRT and RT $(P=0.38)$.

Conclusion: Although relatively fit elderly were assigned to CCHRT, treatment tolerance was worse, especially for those with severe comorbidity. Survival seemed not significantly better as compared to SCHRT or RT. Prospective studies in this vital and understudied area are needed.
\end{abstract}

(c) 2016 Elsevier Ireland Ltd. All rights reserved. Radiotherapy and Oncology 121 (2016) 26-31
Thirty percent of all Non-Small Cell Lung Cancer (NSCLC) patients present with stage III disease [1,2]. A meta-analysis including clinical trials showed the superiority of concurrent chemoradiation (cCHRT) to sequential chemoradiation (sCHRT) for unresectable stage III NSCLC, with a 2- and 5-year survival of $36 \%$ and $15 \%$ for cCHRT and $30 \%$ and $11 \%$ for sCHRT [2]. Mainly fit patients with minimal or no comorbidity were included and only $16 \%$ was aged $\geqslant 70$. Nevertheless, cCHRT is considered standard treatment [2-5]. Alternative curative treatment options are sCHRT [6-8] and radical radiotherapy (RT) [9,10]. Symptom relief and preservation of quality of life $(\mathrm{QoL})$ is offered to patients not

\footnotetext{
* Corresponding author at: Department of Clinical Epidemiology, VieCuri Medical Centre, P.O. Box 1926, 5900 BX Venlo, The Netherlands.

E-mail address: research@viecuri.nl (E.J.M. Driessen).
}

eligible for curative options by palliative care or best supportive care $[7,11]$.

NSCLC is diagnosed at a median age of 70 years and the majority of these patients are poor-risk, indicating poor characteristics for treatment tolerance and prognosis [12,13]. Risk factors for poor treatment tolerance include poor general performance status (PS), polypharmacy, frailty, history of smoking, and extensive smoking-related comorbidity. Other geriatric characteristics such as living situation and functional disability can jeopardize treatment outcomes even more [14-18]. As a result, severe adverse events may occur more often, leading to reduced treatment dose, treatment discontinuation, hospitalization or even death $[2,7,13,19]$. In clinical trials, evidence for treatment regimens is generally assessed in relatively fit and younger patients. These data cannot be extrapolated to the heterogeneous group of NSCLC 
patients in clinical practice, resulting in lack of knowledge on treatment administration for the elderly and poor-risk patients [12$14,16,20]$. In some studies, subset analyses among older patients have been performed to provide information on treatment effects $[1,2,21]$. However, small sample sizes $(N<50)$ lead to lack of solid conclusions and the role of comorbidity, PS and other patient characteristics on treatment tolerance and survival in the elderly receiving chemoradiation (CHRT) remains uncertain $[7,12,16,22,23]$.

The aims of this study were to evaluate treatment strategies, identify motives for omitting cCHRT and determine predictors for treatment tolerance and survival in unselected elderly with unresectable stage III NSCLC in daily clinical practice.

\section{Patients and methods}

Patients were retrieved from the population-based Netherlands Cancer Registry, where trained registrars collect data from patient records like histology and stage of disease with a completeness rate of 95\% [24]. All patients from three Dutch teaching hospitals were selected. Additional information on treatment motives, patient characteristics, treatment tolerance and survival was retrospectively collected from the medical records. Inclusion criteria were age $\geqslant 70$ and a diagnosis of unresectable stage III NSCLC between 2009 and 2013. This period was chosen because of the new TNM staging guidelines in 2009 (TNM Lung Cancer Staging 7th edition [25]) and the ability to collect complete and good quality data retrospectively from medical records. Patients were included from January 1st 2009 until December 31st 2013 and follow-up (FU) was completed until January 31st 2015. Data handling of the unidentifiable data from the Netherlands Cancer Registry was done according to the specifications of the officially recognized Code of Conduct Use of data in health research [26]. Due to the retrospective design, study approval by the medical ethics committee was not mandatory according to the Dutch law 'Medical Research (human subjects) Act' [27]. The following patient characteristics were categorized: Age in years (70-74, 75-79 and 80+), Body Mass Index (BMI) in $\mathrm{kg} / \mathrm{m}^{2}(<22,22-28$ and $>28$ ) [28], histology (adenocarcinoma, squamous cell carcinoma or large cell/Not Otherwise Specified (NOS)), comorbidity according to the Adult Comorbidity Evaluation 27 (ACE-27) (severe comorbidity (severe decompensation in one organ or moderate decompensation in $\geqslant 2$ organs) and no severe comorbidity (no decompensation, mild decompensation in one organ, moderate decompensation in one organ or mild decompensation in $\geqslant 2$ organs)), number of comorbid conditions $(0,1$ or $\geqslant 2)$ and type of comorbidity (cardiovascular, respiratory or renal) [29], World Health Organization Performance Status (WHO PS) $(0-1$ and $\geqslant 2)$ and smoking (current, former and never). Social factors were coded as living independently (yes/no) and living alone (yes/no). Motives for omitting cCHRT were categorized as comorbidity and/or PS, refusal by patient, short life expectancy, high age and other.

Planned treatment options were classified as cCHRT, sCHRT, RT or no curative treatment (including palliative chemotherapy (CT), palliative RT and no active treatment). Regimens for CT consisted of two or three concurrent cis- or carboplatin based doublet cycles or three to four sequential cis- or carboplatin based doublet cycles. Platinum partner CT and number of cycles depended on local hospital protocol. For RT, Gross Tumor Volume (GTV) included the primary tumor and pathologic lymph nodes as identified on the FDGPET scan. During the period 2009-2011, Intensity Modulated Radiotherapy (IMRT) was used, and from 2012 radiotherapy was delivered with an arc technique. Volume constraints for the esophagus were not performed, the maximum point dose in the esophagus was $76 \mathrm{~Gy}$ (biologically equivalent dose in $2 \mathrm{~Gy}$ fractions
(EQD2)). The Clinical Target Volume (CTV) covered an extra margin to include regions at risk of microscopic extension. Planning Target volume (PTV) encompassed a margin for inter- and intrafraction patient and organ motion. Radical RT was defined as delivery of a minimum total tumor dose (TTD) of 54 Gy (EQD2). Possible RT schedules included $33 * 2$ Gy (once daily), $24 * 2.75$ Gy (once daily) or RT according to an individualized prescribed maximal tolerated dose protocol (once or twice daily). RT was delivered using 6-10 MV photons. The dose was specified at $100 \%$ in the ICRU reference point. The dose gradient was $95-115 \%$. Completion of CHRT was determined by receiving a minimal radiation dose of $54 \mathrm{~Gy}$ combined with all planned CT cycles. Completion of RT was achieved when receiving a radiation dose of at least $54 \mathrm{~Gy}$. Treatment tolerance (yes/no) was classified as completion of treatment combined with no unplanned hospitalizations, including hospitalizations for acute radiation esophagitis. Since unplanned hospitalizations are more expected and accepted during cCHRT $[2,6]$, separate analyses were performed for 'completion of treatment' as a measure for treatment tolerance. Overall Survival (OS) was calculated from date of diagnosis of stage III NSCLC until death or until last date of FU and censored. The Consolidated Standards of Reporting Trials (CONSORT) flow-diagram is displayed in Supplemental Fig. 1.

\section{Statistical analyses}

Statistical analyses were performed with IBM SPSS Statistics 22. Patient characteristics were described according to treatment regimen (cCHRT, sCHRT, RT or no curative treatment) and significant differences between treatment regimens were assessed by $\chi^{2}-$ test, Fisher's exact test, or ANOVA $(P<0.05$ two sided). Motives for omitting CCHRT were described ( $N$ and \%). Univariate and multivariate binary logistic regression analyses were performed for treatment tolerance and patient characteristics. The Odds Ratio (OR) and corresponding 95\% Confidence Intervals $(95 \% \mathrm{CI})$ were displayed. Worse treatment tolerance was indicated by $\mathrm{OR}>1.0$. For regression analysis, the backward stepwise method was used with an entry probability of 0.05 and removal of 0.10 . It was assumed that treatment choice partially depended on patient characteristics ('confounding by indication'). Therefore, analyses for treatment tolerance and survival were stratified according to treatment regimen. Kaplan-Meier analyses were performed to assess median OS and significant differences between groups were assessed by the log rank test $(P<0.05)$. Median follow-up was estimated with the reverse Kaplan-Meier method [30]. The Hazard Ratio (HR) and 95\%CI were calculated by Cox regression analyses for survival and patient characteristics. Worse survival was indicated by $\mathrm{HR}>1.0$. In all multivariate analyses, outcomes were determined significant if the $95 \% \mathrm{CI}$ was completely above or below 1.0 .

\section{Results}

A total of 216 elderly patients with unresectable stage III NSCLC were included. Seventy-two received cCHRT (33\%), 52 received sCHRT (24\%), 34 received RT (16\%) and 58 received no curative treatment (27\%). In Table 1 , patient characteristics according to administered treatment are shown. Age $\geqslant 75$, PS $\geqslant 2$ and severe comorbidity were significantly more present in patients not receiving CCHRT $(P<0.05)$. The most common motives for omitting cCHRT were the presence of comorbidity, a poor PS or a combination of both (57\%), and refusal by the patient (15\%). Other motives were short life expectancy (11\%), high age (4\%) and other/unknown (12\%).

Most patients completed administered treatment (71\%,63\% and $80 \%$ for cCHRT, sCHRT and RT, respectively $(P=0.26)$ ). Surprisingly, only $26 \%$ of patients receiving cCHRT tolerated treatment (defined 
Table 1

Overview of patient characteristics according to administered treatment.

\begin{tabular}{|c|c|c|c|c|c|}
\hline $\mathrm{N}(\%)$ & $\begin{array}{l}\text { cCHRT } \\
72(33)\end{array}$ & $\begin{array}{l}\text { sCHRT } \\
52(24)\end{array}$ & $\begin{array}{l}\text { RT } \\
34(16)\end{array}$ & $\begin{array}{l}\text { NCT } \\
58(27)\end{array}$ & $P$-value \\
\hline $\begin{array}{l}\text { Gender } \\
\text { Male } \\
\text { Female }\end{array}$ & $\begin{array}{l}55(76) \\
17(24)\end{array}$ & $\begin{array}{l}44(85) \\
8(15)\end{array}$ & $\begin{array}{l}26(77) \\
8(24)\end{array}$ & $\begin{array}{l}43(74) \\
15(26)\end{array}$ & 0.58 \\
\hline $\begin{array}{l}\text { Age (years) } \\
70-74 \\
75-79 \\
80+\end{array}$ & $\begin{array}{l}39(54) \\
23(32) \\
10(14)\end{array}$ & $\begin{array}{l}15(29) \\
22(42) \\
15(29)\end{array}$ & $\begin{array}{l}3(9) \\
14(41) \\
17(50)\end{array}$ & $\begin{array}{l}18(31) \\
21(36) \\
19(33)\end{array}$ & 0.000 \\
\hline $\begin{array}{l}\text { WHO PS } \\
0-1 \\
2-3 \\
\text { Unknown }\end{array}$ & $\begin{array}{l}69(96) \\
2(3) \\
1(1)\end{array}$ & $\begin{array}{l}36(69) \\
15(29) \\
1(2)\end{array}$ & $\begin{array}{l}20(59) \\
14(41) \\
0(0)\end{array}$ & $\begin{array}{l}17(29) \\
38(66) \\
3(5)\end{array}$ & 0.000 \\
\hline $\begin{array}{l}\text { Comorbidity } \\
\text { No severe } \\
\text { Severe }\end{array}$ & $\begin{array}{l}41(57) \\
31(43)\end{array}$ & $\begin{array}{l}20(39) \\
30(62)\end{array}$ & $\begin{array}{l}12(35) \\
22(65)\end{array}$ & $\begin{array}{l}15(26) \\
43(74)\end{array}$ & 0.000 \\
\hline $\begin{array}{l}\text { Comorbidity N } \\
0 \\
1 \\
\geqslant 2\end{array}$ & $\begin{array}{l}13(18) \\
22(30) \\
37(51)\end{array}$ & $\begin{array}{l}9(17) \\
8(15) \\
35(67)\end{array}$ & $\begin{array}{l}2(6) \\
10(29) \\
22(65)\end{array}$ & $\begin{array}{l}5(9) \\
9(16) \\
44(76)\end{array}$ & 0.05 \\
\hline $\begin{array}{l}\text { Type** } \\
\text { Cardiovascular } \\
\text { Respiratory } \\
\text { Renal }\end{array}$ & $\begin{array}{l}43(60) \\
16(22) \\
4(6)\end{array}$ & $\begin{array}{l}36(69) \\
20(38) \\
2(4)\end{array}$ & $\begin{array}{l}24(71) \\
10(29) \\
1(3)\end{array}$ & $\begin{array}{l}43(74) \\
23(40) \\
4(7)\end{array}$ & $\begin{array}{l}0.84 \\
0.23 \\
0.66\end{array}$ \\
\hline $\begin{array}{l}\text { BMI }\left(\mathrm{kg} / \mathrm{m}^{2}\right) \\
\quad<22 \\
22-28 \\
>28 \\
\text { Unknown }\end{array}$ & $\begin{array}{l}10(14) \\
42(58) \\
20(28) \\
0(0)\end{array}$ & $\begin{array}{l}5(10) \\
33(64) \\
14(27) \\
0(0)\end{array}$ & $\begin{array}{l}4(12) \\
15(44) \\
11(32) \\
4(12)\end{array}$ & $\begin{array}{l}8(14) \\
29(50) \\
11(19) \\
10(17)\end{array}$ & 0.83 \\
\hline $\begin{array}{l}\text { Smoking } \\
\text { Current } \\
\text { Former } \\
\text { Never } \\
\text { Unknown }\end{array}$ & $\begin{array}{l}29(40) \\
39(54) \\
2(3) \\
2(3)\end{array}$ & $\begin{array}{l}18(35) \\
33(64) \\
1(2) \\
0(0)\end{array}$ & $\begin{array}{l}9(27) \\
16(47) \\
2(6) \\
7(21)\end{array}$ & $\begin{array}{l}22(38) \\
26(45) \\
3(5) \\
7(12)\end{array}$ & 0.73 \\
\hline $\begin{array}{l}\text { Histology } \\
\text { Squamous CC } \\
\text { Adenocarcinoma } \\
\text { NOS/large CC }\end{array}$ & $\begin{array}{l}23(32) \\
17(24) \\
32(44)\end{array}$ & $\begin{array}{l}15(30) \\
7(14) \\
28(56)\end{array}$ & $\begin{array}{l}5(15) \\
7(21) \\
22(65)\end{array}$ & $\begin{array}{l}15(26) \\
17(29) \\
26(45)\end{array}$ & 0.2 \\
\hline $\begin{array}{l}\text { Living independent } \\
\text { Independent } \\
\text { Dependent } \\
\text { Unknown }\end{array}$ & $\begin{array}{l}68(96) \\
3(4) \\
1(1)\end{array}$ & $\begin{array}{l}49(94) \\
3(6) \\
0(0)\end{array}$ & $\begin{array}{l}27(79) \\
4(12) \\
3(9)\end{array}$ & $\begin{array}{l}44(76) \\
7(12) \\
7(12)\end{array}$ & 0.19 \\
\hline $\begin{array}{l}\text { Living alone } \\
\text { Alone } \\
\text { Not alone } \\
\text { Unknown }\end{array}$ & $\begin{array}{l}31(43) \\
40(56) \\
1(1)\end{array}$ & $\begin{array}{l}18(35) \\
34(65) \\
0(0)\end{array}$ & $\begin{array}{l}13(38) \\
16(47) \\
5(15)\end{array}$ & $\begin{array}{l}27(47) \\
25(43) \\
6(10)\end{array}$ & 0.36 \\
\hline $\begin{array}{l}\text { Platinum type } \\
\text { Carboplatin } \\
\text { Cisplatin } \\
\text { Unknown }\end{array}$ & $\begin{array}{l}29(40) \\
42(58) \\
1(1)\end{array}$ & $\begin{array}{l}25(48) \\
19(37) \\
8(15)\end{array}$ & NA & NA & 0.1 \\
\hline
\end{tabular}

Figures are displayed as $N(\%)$ 'Number (percentage)', the $P$-value is based on known data, abbreviations: CC 'Cell Carcinoma', cCHRT 'concurrent chemoradiation', NA 'Not Applicable', NCT 'No Curative Treatment', NOS 'Not Otherwise Specified', sCHRT 'sequential chemoradiation', RT 'radical radiotherapy', WHO PS 'World Health Organization Performance Status', ${ }^{* *}$ comorbidity type: mild, moderate and severe comorbidities combined, the percentage could exceed $100 \%$ since $>60 \%$ of patients have $\geqslant 2$ comorbidities.

as completed treatment without unplanned hospitalizations) compared to $40 \%$ for sCHRT and $59 \%$ for RT $(P=0.000)$. Additionally, patients undergoing CHRT with severe comorbidity had significantly worse treatment tolerance compared to patients without severe comorbidity (OR 6.2 (95\%CI 1.6-24) for cCHRT and OR 6.4 (95\%CI 1.8-22) for sCHRT, Fig. 1 and Table 2). The same trend was seen in patients with $\geqslant 2$ comorbid conditions compared to no comorbidity (OR 7.1 (95\%CI 1.6-32) for cCHRT and OR 6.5 (95\%CI 1.3-32) for sCHRT). No other significant associations between treatment tolerance and characteristics were found.

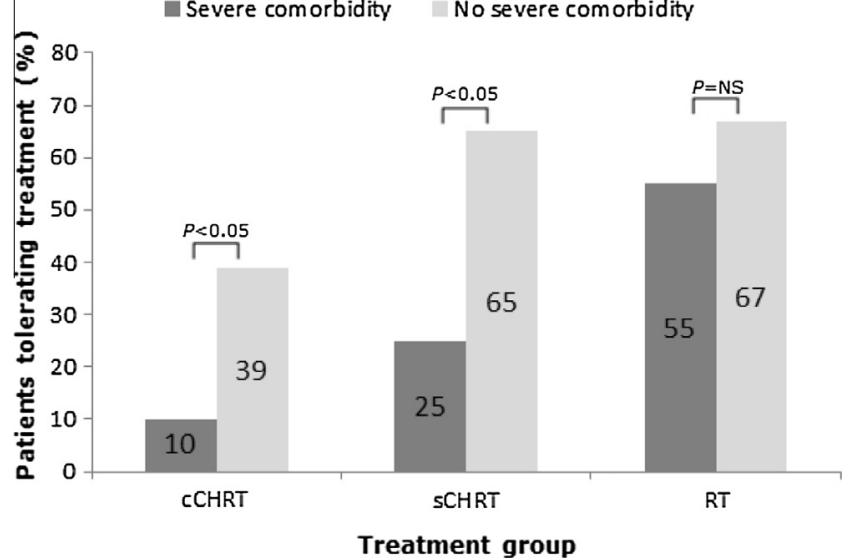

Fig. 1. Percentage of patients tolerating treatment (completion of treatment and no unplanned hospitalizations) per treatment and comorbidity group, abbreviations: cCHRT 'concurrent chemoradiation', sCHRT 'sequential chemoradiation', RT 'radical radiotherapy', NS ' Not Significant'.

Table 2

Odds Ratios (ORs) for predictors of treatment tolerance stratified for cCHRT and sCHRT (treatment tolerance $=$ completion of treatment and no unplanned hospitalizations).

\begin{tabular}{|c|c|c|c|c|}
\hline Predictor & $\begin{array}{l}\text { Unadjusted OR } \\
(95 \% \mathrm{CI})\end{array}$ & $P$-value & $\begin{array}{l}\text { Adjusted OR } \\
(95 \% \mathrm{CI})\end{array}$ & $P$-value \\
\hline \multicolumn{5}{|l|}{ cCHRT } \\
\hline \multicolumn{5}{|l|}{ Age } \\
\hline $70-74$ & Reference & & \multirow{3}{*}{ NA } & \\
\hline $75-79$ & $0.69(0.22-2.2)$ & 0.52 & & \\
\hline $80+$ & $0.70(0.15-3.3)$ & 0.65 & & \\
\hline \multicolumn{5}{|l|}{ WHO PS } \\
\hline 0-1 & Reference & & \multirow{2}{*}{\multicolumn{2}{|c|}{ NA }} \\
\hline $2-3$ & NA & 0.99 & & \\
\hline \multicolumn{5}{|l|}{ Comorbidity } \\
\hline No severe & Reference & & \multicolumn{2}{|l|}{ Reference } \\
\hline Severe & $6.0(1.6-23)$ & 0.009 & $6.2(1.6-24)$ & 0.008 \\
\hline \multicolumn{5}{|l|}{ sCHRT } \\
\hline \multicolumn{5}{|l|}{ Age } \\
\hline 70-74 & Reference & & \multirow{3}{*}{ NA } & \\
\hline $75-79$ & $1.1(0.26-4.3)$ & 0.92 & & \\
\hline $80+$ & $0.33(0.08-1.5)$ & 0.15 & & \\
\hline \multicolumn{5}{|l|}{ WHO PS } \\
\hline 0-1 & Reference & & \multirow{2}{*}{\multicolumn{2}{|c|}{ NA }} \\
\hline $2-3$ & $2.2(0.59-8.2)$ & 0.24 & & \\
\hline \multicolumn{5}{|l|}{ Comorbidity } \\
\hline No severe & Reference & & Reference & \\
\hline Severe & $5.6(1.6-23)$ & 0.006 & $6.4(1.8-22)$ & 0.004 \\
\hline
\end{tabular}

Figures are displayed as OR $(95 \% \mathrm{CI})$ 'Odds Ratio (95\% Confidence Interval)', abbreviations: cCHRT 'concurrent chemoradiation', NA 'Not Applicable', sCHRT 'sequential chemoradiation', WHO PS 'World Health Organization Performance Status', $\mathrm{OR}>1.0$ indicates worse treatment tolerance, none of the unadjusted predictors was significant for radical radiotherapy.

Overall median FU was 47 months. Median OS and 1- and 2year survival for cCHRT were 18 months (95\%CI 9.2-27), 57\% and $21 \%$, respectively (Fig. 2). For sCHRT, this was 12 months (95\%CI 7.5-17), 50\% and 17\%, respectively. For RT, these figures were 11 months (95\%CI 5.5-16), 49\% and 14\%, respectively, and for no curative treatment 5 months (95\%CI $1.6-8.4), 26 \%$ and $4 \%$, respectively. In multivariate analyses, OS for patients who received no curative treatment was significantly worse compared to those who received curative treatment options (HR 2.9 (95\%CI 1.9-4.3) $P=0.000$ ). However, cCHRT did not show significant superior OS compared to sCHRT or RT (HR 1.2 (95\%CI 0.82-1.8) and HR 1.3 (95\%CI $0.81-2.0$ ), respectively $P=0.38$ ). The stratified results of unadjusted and adjusted HRs for survival are shown in Table 3. 


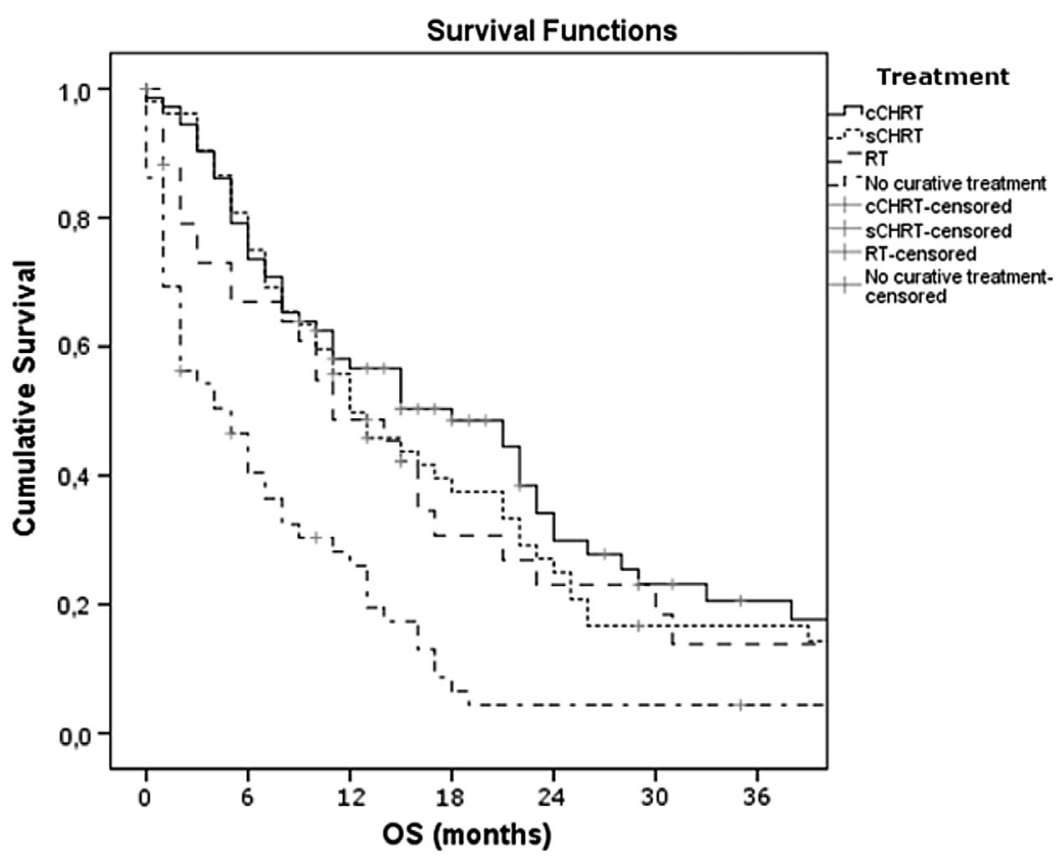

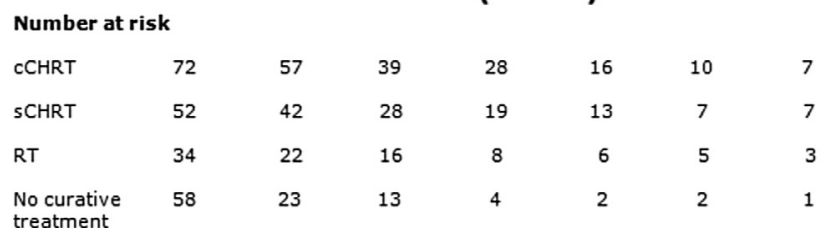

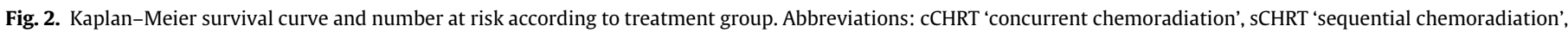
RT 'radical radiotherapy', OS ‘overall survival'.

Table 3

Hazard Ratios (HRs) for predictors of survival stratified for cCHRT and sCHRT.

\begin{tabular}{|c|c|c|c|c|}
\hline Predictor & $\begin{array}{l}\text { Unadjusted HR } \\
(95 \% \mathrm{CI})\end{array}$ & $P$-value & $\begin{array}{l}\text { Adjusted HR } \\
(95 \% \mathrm{CI})\end{array}$ & $P$-value \\
\hline \multicolumn{5}{|l|}{ cCHRT } \\
\hline \multicolumn{5}{|l|}{ Age } \\
\hline $70-74$ & Reference & & & \\
\hline $75-79$ & $0.94(0.50-1.8)$ & 0.86 & NA & \\
\hline $80+$ & $1.7(0.74-3.7)$ & 0.22 & & \\
\hline \multicolumn{5}{|l|}{ WHO PS } \\
\hline 0-1 & Reference & & & \\
\hline $2-3$ & $1.6(0.37-6.5)$ & 0.55 & NA & \\
\hline \multicolumn{5}{|l|}{ Comorbidity } \\
\hline No severe & Reference & & Reference & \\
\hline Severe & $2.0(1.1-3.5)$ & 0.024 & $2.1(1.1-3.7)$ & 0.017 \\
\hline \multicolumn{5}{|l|}{ sCHRT } \\
\hline \multicolumn{5}{|l|}{ Age } \\
\hline $70-74$ & Reference & & Reference & \\
\hline $75-79$ & $0.42(0.2-0.84)$ & 0.014 & $0.42(0.2-0.84)$ & 0.014 \\
\hline $80+$ & $0.94(0.44-2.0)$ & 0.86 & $0.89(0.41-1.9)$ & 0.76 \\
\hline \multicolumn{5}{|l|}{ WHO PS } \\
\hline 0-1 & Reference & & & \\
\hline $2-3$ & $0.91(0.48-1.7)$ & 0.78 & NA & \\
\hline \multicolumn{5}{|l|}{ Comorbidity } \\
\hline No severe & Reference & & & \\
\hline Severe & $0.76(0.42-1.4)$ & 0.35 & NA & \\
\hline
\end{tabular}

Figures are displayed as HR (95\%CI) 'Hazard Ratio (95\% Confidence Interval)', abbreviations: cCHRT 'concurrent chemoradiation', NA 'Not Applicable', sCHRT 'sequential chemoradiation', WHO PS 'World Health Organization Performance Status', HR $>1.0$ indicates worse survival, none of the unadjusted predictors was significant for radical radiotherapy or no curative treatment.

Among patients receiving cCHRT, those with severe comorbidity had significant worse (median) survival compared to patients without severe comorbidity (22 months (95\%CI 13-31) and 15 months (95\%CI 8.0-22), respectively $(P=0.019)$ and HR 2.0
(95\%CI 1.1-3.5)). Survival for patients aged 75-79 receiving sCHRT was superior compared to ages 70-74 (HR 0.42 (95\%CI 0.21-0.84)). The number of comorbid conditions was not associated with worse survival for both cCHRT and SCHRT. For RT and no curative treatment, none of the patient characteristics were associated with superior or worse survival. As $>60 \%$ of patients had two or more mild, moderate or severe comorbid conditions, types of comorbidity were not included into multivariate analyses.

\section{Discussion}

This study aimed to evaluate administered treatment, motives for omitting CCHRT and predictors for treatment tolerance and survival in unselected elderly patients with unresectable stage III NSCLC in daily clinical practice. The most common motives for omitting cCHRT were comorbidity and/or poor PS and patient refusal. Worse treatment tolerance and survival were found for severe comorbidity and survival was not significantly superior for cCHRT compared to sCHRT or RT.

The proportion of patients receiving cCHRT (33\%) was comparable to other elderly-specific studies (33-41\%) [14,22] and less often administered to patients aged $\geqslant 75$ with PS $\geqslant 2$ and severe comorbidity. Both PS and comorbidity are important indications for treatment toxicity and survival as reflected by the most common motives for omitting cCHRT and should be analyzed carefully before treatment decision-making $[5,7,9,21]$. Not choosing intensive treatment could originate from cherishing a good QoL instead of longer survival time at the end of life $[7,11]$.

Toxicity rates are generally higher in unselected patients compared to selected patients in clinical trials [19]. PS, comorbidity and age could be predictors for treatment toxicity $[31,32]$. Presumably, PS is a stronger and more robust risk factor than 
comorbidity due to assessment at diagnosis $[7,21]$. However, ACE27 can provide more detailed information to distinguish patients eligible for cCHRT or SCHRT due to a time window of events and severity of organ decompensation $[17,21,29,33]$. In the present study, severe comorbidity ( $\geqslant 1$ severe or $\geqslant 2$ moderate decompensations) and $\geqslant 2$ comorbid conditions indicated worse treatment tolerance for cCHRT and sCHRT (unplanned hospitalizations and/ or not completing treatment). COPD (Chronic Obstructive Pulmonary Disease) is common among NSCLC-patients and can increase pulmonary toxicity when treated intensively [23]. Although the number of comorbid conditions is easier to use during clinical evaluation, investigating severity of comorbidity is preferable since it can be informative for both treatment tolerance and survival. Radiation esophagitis is common as well, especially for CCHRT, and may result in hospitalization, treatment interruption and worse treatment outcomes [34,35]. Despite that hospitalizations were common for CHRT, the majority completed treatment as proper symptom management was applied. Radiotherapy technique can be related to treatment completion and tolerance [34,35]. Despite of changes in techniques during this cohort, tolerance outcomes were not significantly different through included years $(P=0.95)$. Since dose volume data for organs at risk were not available, it remains uncertain whether synergistic effects of comorbidity, organ dose volumes, radiation esophagitis and other adverse events decreased treatment tolerance in multimodality treatment [36-38].

Median survival after cCHRT was not significantly superior compared to sCHRT or RT. This is in contrast to a meta-analysis and population-based study in which survival was superior for cCHRT compared to sCHRT. Although this might be explained by lack of power in the current study, this could also be due to the fact that only younger patients and/or fit elderly were included which does not represent daily practice $[1,2]$. Older patients are often treated less aggressive because of toxicity risk and potential worse survival $[14,15,21]$. On the contrary, patients aged $75-79$ years receiving sCHRT had better survival compared to ages $70-74$. This is probably due to selection of the fittest elderly and can indicate that functional age instead of high age provides a broader view on possible treatment tolerance and survival [32]. PS was not found to be a significant predictor for survival in multivariate analyses. Scoring of PS is physician dependent and therefore could be more subjective. Also, correcting for two strongly related outcomes like PS and comorbidity in a multivariate model can lead to inclusion of the most explanatory only [21], which would be comorbidity in this case. In case of cCHRT, severe comorbidity was predictive for worse treatment tolerance and worse median survival compared to no severe comorbidity. The Raditux trial also found shorter survival in case of cCHRT and comorbidity and indicated the need for studies investigating (severe) comorbidity and treatment outcomes [23]. Possibly, worse survival for cCHRT could also be explained by poor-risk patients receiving carboplatin more often and higher survival rates can be reached in selected patients receiving cisplatin [39]. Due to minor differences in survival and less adverse events, it can be suggested that sCHRT is more feasible than cCHRT in unselected elderly [4] and RT remains an alternative for CHRT in patients with severe comorbidity $[9,10]$. However, cCHRT should not be denied to selected elderly patients $[14,19,40]$. The strengths of our study are the high external validity and patient inclusion between 2009 and 2013. This provides fairly recent and demonstrative patient data which are generalizable to other unselected elderly NSCLC patients. Data quality and completeness were good since both medical files and the Netherlands Cancer Registry were used for retrieval. In addition, all patients were diagnosed and staged completely, including PET/CT. A weakness of this study is that due to the retrospective observational design, physicians selected the best suitable therapy for the patient and randomization has not been performed. However, analyses were stratified to take into account 'confounding by indication'. Some data regarding social factors were incomplete and could not be included in the analyses. A formal geriatric assessment is not included in standard care, and as such, we could not include extensive geriatric characteristics or a weighted geriatric score. An explanation for not detecting significant differences between curative options could be lack of statistical power, as the number of patients required for detecting a significant and clinically meaningful difference for survival could not be included $(>100$ per treatment arm). Also, median FU was shorter for cCHRT (35 months) compared to sCHRT (62 months) and RT (47 months) and a relatively high proportion of patients receiving cCHRT was still alive at the end of the study period and censored. This might explain why long-term superiority of CCHRT over SCHRT for the elderly could not yet be supported. Although this study was underpowered and conclusions should be drawn carefully, the negative impact of comorbidity on treatment tolerance and survival is potentially true.

Especially for the elderly, the goals and preferences of the patient regarding survival, QoL and tolerance of treatment are important to take into consideration in multidisciplinary decision-making. Consequently, there is a need for elderly-specific prospective observational studies addressing patient preferences, the role of severe comorbidity in treatment tolerance and survival and the probable survival benefit of cCHRT compared to both sCHRT and RT [10]. Comprehensive Geriatric Assessments (GCA) should be included to examine geriatric characteristics and QoL during and after treatment, in order to provide a weighted score for geriatric characteristics to assess treatment outcomes and provide the best suitable treatment for each patient $[13,14,32,33]$. These issues are largely addressed in the prospective randomized trial ELDAPT (NCT02284308), which has started recently in the Netherlands. The results of ELDAPT can facilitate treatment decision making since patient preferences and capacities can be collected more precisely and interpreted in the light of a geriatric view [7,33].

In conclusion, comorbidity, poor PS and patient refusal were the most common motives for omitting CCHRT. Despite the fact that relatively fit and younger elderly were assigned to cCHRT, treatment tolerance was worse for patients receiving cCHRT, especially for those with severe comorbidity. Only minor differences in survival between CCHRT, sCHRT and RT were found. This means that sCHRT or RT might be more feasible treatment options for the elderly. Future prospective studies should focus on patient preferences, (severe) comorbidity, predictive geriatric characteristics and include quality of life or functionality as important end points. As a result, more evidence can be gathered for treatment decisions in elderly patients with unresectable NSCLC, leading to the most optimal balance between quality of life and survival.

\section{Conflict of interest statement}

None declared.

\section{Appendix A. Supplementary data}

Supplementary data associated with this article can be found, in the online version, at http://dx.doi.org/10.1016/j.radonc.2016.07. 025.

\section{References}

[1] van der Drift MA, Karim-Kos HE, Siesling S, et al. Progress in standard of care therapy and modest survival benefits in the treatment of Non-small Cell Lung Cancer patients in the Netherlands in the last 20 years. J Thorac Oncol 2012;7:291-8. 
[2] Aupérin A, le Péchoux C, Rolland E, et al. Meta-analysis of concomitant versus sequential radiochemotherapy in locally advanced non-small-cell lung cancer. J Clin Oncol 2010;28:2181-90.

[3] Albain KS, Swann RS, Rusch VW, et al. Radiotherapy plus chemotherapy with or without surgical resection for stage III non-small-cell lung cancer: a phase III randomised controlled trial. Lancet 2009;374:379-86.

[4] Curran WJ, Paulus R, Langer CJ, et al. Sequential vs concurrent chemoradiation for stage III non-small cell lung cancer: randomized phase III trial RTOG 9410. J Natl Cancer Inst 2011:103:1452-60.

[5] Eberhardt WE, de Ruysscher D, Weder W, et al. 2nd ESMO Consensus Conference in Lung Cancer: locally advanced stage III non-small-cell lung cancer. Ann Oncol 2015;26:1573-88.

[6] Firat S, Byhardt RW, Gore E. The effects of comorbidity and age on RTOG study enrollment in stage III non-small cell lung cancer patients who are eligible for RTOG studies. Int J Radiat Oncol Biol Phys 2010;78:1394-9.

[7] Blanco R, Maestu I, de la Torre MG, Cassinello A, Nuñez I. A review of the management of elderly patients with non-small-cell lung cancer. Ann Oncol 2015;26:451-63.

[8] Atagi S, Kawahara M, Yokoyama A, et al. Thoracic radiotherapy with or without daily low-dose carboplatin in elderly patients with non-small-cell lung cancer: a randomised, controlled, phase 3 trial by the Japan Clinical Oncology Group (JCOG0301). Lancet Oncol 2012;13:671-8.

[9] Joo JH, Song SY, Kim SS, et al. Definitive radiotherapy alone over 60 Gy for patients unfit for combined treatment to stage II-III non-small cell lung cancer: retrospective analysis. Radiat Oncol 2015;10:250.

[10] Sigel K, Lurslurchachai L, Bonomi M, et al. Effectiveness of radiation therapy alone for elderly patients with unresected stage III non-small cell lung cancer. Lung Cancer 2013;82:266-70.

[11] Temel JS, Greer JA, Muzikansky A, et al. Early palliative care for patients with metastatic non-small-cell lung cancer. N Engl J Med 2010;363:733-42.

[12] Gridelli C, Langer C, Maione P, Rossi A, Schild SE. Lung cancer in the elderly. J Clin Oncol 2007;25:1898-907.

[13] Cardenal F, Nadal E, Jové M, Faivre-Finn C. Concurrent systemic therapy with radiotherapy for the treatment of poor-risk patients with unresectable stage III non-small-cell lung cancer: a review of the literature. Ann Oncol 2015;26:278-88.

[14] Semrau S, Zettl H, Hildebrandt G, Klautke G, Fletkau R. Older patients with inoperable non-small cell lung cancer. Strahlenther Onkol 2014;190:1125-32.

[15] Hsu C-L, Chen J-H, Chen K-Y, et al. Advanced non-small cell lung cancer in the elderly: the impact of age and comorbidities on treatment modalities and patient prognosis. J Geriatr Oncol 2015;6:38-45.

[16] Pallis AG, Gridelli C, Wedding U, et al. Management of elderly patients with NSCLC; updated expert's opinion paper: EORTC Elderly Task Force, Lung Cancer Group and International Society for Geriatric Oncology. Ann Oncol 2014;25:1270-83.

[17] Grose D, Morrison DS, Devereux G, et al. The impact of comorbidity upon determinants of outcome in patients with lung cancer. Lung Cancer 2015;87:186-92.

[18] Glotzer OS, Fabian T, Chandra A, Bakhos CT. Non-small cell lung cancer therapy: safety and efficacy in the elderly. Drug Healthc Patient Saf 2013;5:113-21.

[19] Kale MS, Mhango G, Gomez JE, et al. Treatment toxicity in elderly patients with advanced non-small cell lung cancer. Am J Clin Oncol 2015 [Epub ahead of print].

[20] Wanders R, Steevens J, Botterweck A, et al. Treatment with curative intent of stage III non-small cell lung cancer patients of 75 years: a prospective population-based study. EJC 2011;47:2691-7.

[21] Mellemgaard A, Lüchtenborg M, Iachina $M$, et al. Role of comorbidity on survival after radiotherapy and chemotherapy for nonsurgically treated lung cancer. J Thorac Oncol 2015;10:272-9.
[22] de Ruysscher D, Botterweck A, Dirx M, et al. Eligibility for concurrent chemotherapy and radiotherapy of locally advanced lung cancer patients: a prospective, population-based study. Ann Oncol 2009;20:98-102.

[23] Walraven I, van den Heuvel M, van Diessen J, et al. Long-term follow-up of patients with locally advanced non-small cell lung cancer receiving concurrent hypofractioned chemoradiotherapy with or without cetuximab. Radiother Oncol 2016;118:442-6.

[24] Schouten LJ, Höppener P, van den Brandt PA, Knottnerus JA, Jager JJ. Completeness of cancer registration in Limburg, the Netherlands. Int J Epidemiol 1993;22:369-76.

[25] American Joint Committee on Cancer. TNM lung cancer staging. 7th ed. Memorial Sloan-Kettering Cancer Center; 2009.

[26] Federation of Medical Science Societies, Information CPP. Code of Conduct Use of data in health research 2004 [cited 2015]. Available from: <https://www. federa.org/sites/default/files/bijlagen/coreon/gedragscode_ gezondheidsonderzoek.pdf>.

[27] Borst-Eilers E, Sorgdrager W. Act of February 26th 1998: Medical Research (human subjects) Act. Department of Health, Welfare and Sports and Department of Justice; 1998.

[28] Dutch National Working Group of Oncology Dieticians. BMI in the elderly: Comprehensive Cancer Centre the Netherlands (IKNL); 2012 [Mar 14th 2015]. Available from: <www.oncoline.nl>.

[29] Kallogjeri D, Piccirillo JF, Spitznagel EL, Steyerberg EW. Comparison of scoring methods for ACE-27: simpler is better. J Geriatr Oncol 2012;3:238-45.

[30] Schemper M, Smith TL. A note on quantifying follow-up in studies of failure time. Control Clin Trials 1996;17:343-6.

[31] Maione P, Perrone F, Gallo C, et al. Pretreatment quality of life and functional status assessment significantly predict survival of elderly patients with advanced non-small-cell lung cancer receiving chemotherapy: a prognostic analysis of the multicenter Italian lung cancer in the elderly study. J Clin Oncol 2005;23:6865-72.

[32] Handforth C, Clegg A, Young C, et al. The prevalence and outcomes of frailty in older cancer patients: a systematic review. Ann Oncol 2015;26:1091-101.

[33] Gosney MA. Clinical assessment of elderly people with cancer. Lancet Oncol 2005;6:790-7.

[34] Pan Y, Brink C, Knap M, et al. Acute esophagitis for patients with local-regional advanced non small cell lung cancer treated with concurrent chemoradiotherapy. Radiother Oncol 2016.

[35] Wijsman R, Dankers F, Troost EG, et al. Multivariable normal-tissue complication modeling of acute esophageal toxicity in advanced stage nonsmall cell lung cancer patients treated with intensity-modulated (chemo-) radiotherapy. Radiother Oncol 2015;117:49-54.

[36] Petit SF, van Elmpt W. Accurate prediction of target dose-escalation and organat-risk dose levels for non-small cell lung cancer patients. Radiother Oncol 2015;117:453-8.

[37] Coffey M, Leech M, Poortmans P. Benchmarking Radiation TherapisT (RTT) education for safe practice: the time is now. Radiother Oncol 2016:119:12-3.

[38] Bradley JD, Paulus R, Komaki R, et al. Standard-dose versus high-dose conformal radiotherapy with concurrent and consolidation carboplatin plus paclitaxel with or without cetuximab for patients with stage IIIA or IIIB nonsmall-cell lung cancer (RTOG 0617): a randomised, two-by-two factorial phase 3 study. Lancet Oncol 2015;16:187-99.

[39] Santana-Davila R, Devisetty K, Szabo A, et al. Cisplatin and etoposide versus carboplatin and paclitaxel with concurrent radiotherapy for stage III nonsmall-cell lung cancer: an analysis of Veterans Health Administration data. JCO 2015;33:567-74.

[40] de Ruysscher D, Dehing C, Bentzen SM, et al. Can we optimize chemo-radiation and surgery in locally advanced stage III non-small cell lung cancer based on evidence from randomized clinical trials? A hypothesis-generating study. Radiother Oncol 2009;93:389-95. 